\title{
Prostor ideologie. Varianty motivu sídliště v současné české próze
}

Karel Střelec

\begin{abstract}
The Space of Ideology. Variants of the Motif of Housing Estates in Contemporary Czech Prose ${ }^{1}$

The housing estates represent one of the newest forms of urban space which mass expansion over several decades has significantly altered the character of not only Czech cities. Our contribution focuses on the representation of the housing estates, its varieties and its forms in the latest Czech prose. On a selected sample of works the paper follows the character and identity of this space and it deals with assessing the presence of ideological influences in the memory of place. In some cases, also the contemporary literary image of the housing estate is compared to older literary works that originated during the period of normalization.
\end{abstract}

\section{KEYWORDS}

Contemporary Czech prose; Ideology; Topos of housing estates; Memory; Literary place names.

\section{KLÍčovÁ SLOVA}

Současná česká próza; ideologie; topos sídliště; pamět; literární toponyma.

1) Překlad citací z angličtiny a francouzštiny: autor. 


\section{Úvod - prostor a ideologie}

Svébytnou součástí revoluční komunistické ideologie je formování veřejného městského prostoru; již v období první republiky nacházely v Československu u levicově orientovaných architektů ohlas projekty městských celků, budova(1) ných v Sovětském svazu. Architektura a urbanismus měly spoluutvářet obraz socialistické společnosti a jednoznačně ji odlišit od společnosti kapitalistické (STRAKOŠ 2011: 204). Tyto představy po ukončení stavebních realizací v duchu socialistického realismu vedly od přelomu 50. a 60. let $\mathrm{k}$ dekádám, během nichž se zásadním projevem socialistického stavebnictví ve městech staly sídlištní celky.

Jeden $\mathrm{z}$ aspektů snahy o realizaci komunistických idejí představovala proměna prostoru každodenní lidské zkušenosti - kvalitativní i kvantitativní měřítka prostoru totiž úzce souvisí s celkovým uspořádáním společnosti, jejím charakterem a strukturou. Socialistické sídliště nezbytně odráží ideologické hodnoty: „Zrušení soukromého vlastnictví, odstranění privilegovaných vrstev a realizace principu rovnosti prosazována marxistickou či socialistickou ideologií by měla zásadním zpo̊sobem změnit obraz města. V oblasti bydlení bude v obecné rovině směřováno $\mathrm{k}$ takovému typu, který nebude mezi lidmi rozlišovat, nebude diskriminační ani z hlediska prostoru. Žádná společenská nebo profesní skupina by neměla mít příznivěji umístěné nebo lepší bydliště [...]“ (DEMKO - REGULSKA 1987: 290). Lze tedy konstatovat, že sídliště se stávají reálným materiálním vyjádřením oficiální státní ideologie v opozici ke starším částem městského prostoru (vznikajícím od středověku až po období kapitalismu).

Vzhledem k tomu, že marxistická ideologie přikládá bydlení prioritní význam, musel dobový urbanismus na její požadavky reagovat (ANDRUSZ 1987: 478-499). Základním principem výstavby je přitom rovnost a kolektivní báze - minimální diferenciace je zřetelná mezi jednotlivými bytovými jednotkami a jejím vybavením, mezi vnějším designem standardizovaných domů, ale také v podobě uspořádání ulic, prostranství a dokonce jednotlivých čtvrtí. Aspekt identičnosti se plně rozvíjí od počátku 60 . let, kdy je definitivně upuštěno od architektury tzv. socialistického realismu. ${ }^{2}$ Dalšími klíčovými atributy, jež ideologie vkládá do vytváření urbánního prostoru, jsou striktní odlišení sídlištních celků od míst výroby a průmyslu (na rozdíl např. od 19. století, kdy docházelo k prorůstání industriálních podniků do obytných zón), snaha o centralizované umístění služeb a obchodů či přítomnost dekorativních objektů s ideologicky

2) I přes odlišné provedení fasád budov je záměr unifikace a rovnosti přítomen v exteriérech a interiérech rovněž v tomto období. 
vhodnými náměty (sochy, fontány, památníky, mozaiky apod.). V neposlední řadě je prostor záměrně „osazen“ honorifikačními toponymy, upomínající na osobnosti či události spjaté s budováním socialistické společnosti. Tyto a další projevy státní ideologie kombinují implicitní a explicitní působení; skrytě vyjádřená ideologie se tak v prostoru socialistického sídliště mísí s ideologií otevřeně deklarovanou. ${ }^{3}$

\section{Reprezentace vztahu sídliště a ideologie}

Krátký úvodní exkurz, týkající se nefikčního, aktuálního světa, otevírá otázky po způsobu literární reflexe sídlištního prostoru ve vztahu k politické ideologii. Zajímají nás podoby fikčního prostoru sídliště v současné české próze s ohledem na to, jak je jeho obraz spjat s komunistickou ideologií a zda se tato ideologie stala přetrvávající součástí paměti místa. ${ }^{4}$ Nejde o vyčerpávající uchopení uvedené problematiky; téma pojímáme formou dílčích sond a analýz výběru $z$ děl vydaných po roce 2000. Téma nahlížíme také s ohledem na aktuální poznatky pamětových studií a na přístupy, které přinesl tzv. prostorový obrat v literární vědě, jehož východiskem je širší, interdisciplinární pojetí zkoumání městského prostoru. ${ }^{5}$

Jan Lukavec ve svém zamyšlení z roku 2012 nad reprezentacemi sídliště v literatuře konstatuje, že „po roce 1989 jako by u nás románů a povídek s tematikou sídlišt zřejmě ubylo" (LUKAVEC 2012). Připomíná přitom plejádu próz ze 70. a 80. let minulého století, v nichž je právě tento prostor klíčovou konstantou. Je logické, že umělecká reflexe panelových sídlišt byla vyšší v době, kdy se jednalo o relativně nový sociálně-urbánní fenomén; nelze však nepřipomenout, že i v nejnovější české literatuře jde o topos častý. ${ }^{6}$

3) Proměnám vnímání ideologičnosti sídlišt’ v postsocialistických zemích se věnuje mj. podnětná studie Barbory Novotné, která s využitím konceptu tzv. „hraniční krajiny“ Mariusze Czepczyńského nastiňuje otázku, zda z paměti panelových čtvrtí může symbolika komunismu vůbec kdy vymizet. Poukazuje na každodennost kontaktu společnosti se sídlišti a současně na jejich výraznou stopu v české krajině: „Hodnota paneláků v historické paměti spočívá v tom, že jsou živou vzpomínkou na komunismus a tíživou minulostí promítnutou do krajiny. V dnešní době se symbolický význam paneláků teprve formuje, je ale pravděpodobné, že se ustaví jako místo paměti v postliminální fázi transformace krajiny“ (NOVOTNÁ 2010: 130).

4) Jak ostatně uvádí Karen Grumberg ve své monografii Place and Ideology in Contemporary Hebrew Literature věnované ideologii a místům v izraelské literatuře, každá ideologie ovlivňuje charakter prostoru. Srov. GRUMBERG $2011: 13$.

5) Dorris Bachmann-Medick v této souvislosti upozorňuje, že literárněvědné bádání v problematice prostoru jsou dílčí součástí obecného výzkumu v politicko-kulturním kontextu. Srov. ZMĚLÍK 2011: 31-33.

6) Nepochybně bude zajímavé sledovat rovněž literární ztvárnění a zpracování tohoto toposu v budoucnu, a to s ohledem na jeho ustupující ustálené (zpravidla negativní) společenské vnímání. Dokladem toho mohou být projekty či výstavy posledních let věnované panelové výstavbě, uměleckým realizacím v sídlištních lokalitách nebo reflexi paneláků ve vizuálním umění. 
Jedno z nejvýraznějších zpracování obrazu sídliště v naší nejnovější próze představuje satiricko-apokalyptický román Strážci občanského dobra Petry Hůlové. Město Krakov (zcela tvořené sídlištní zástavbou) se v něm samo stává tématem, přesahující svými významy kategorii fikčního prostoru. Krakov je sídlištěm typickým, jeho nevýlučnost navíc podtrhuje výstavba dalších sídel, pojmenovaných po velkých městech východního bloku. ${ }^{7}$ Již jeho samotný vznik a pojmenování proto odráží socialistickou ideologii a akcentuje její nadnárodní význam, přičemž má za cíl také ukázat na schopnost státu procházet vývojem, reagovat na aktuální potřeby; vypravěčka a současně ústřední postava, přesvědčená komunistka, retrospektivně zdůrazňuje: „Měla snad Ostrava-Poruba mít monopol na to, co znamená stavět se novodobě na odiv?" (HŮLOVÁ 2010: 14).

Vzniknuvši na zelené louce v 70. letech, postrádá město jakoukoliv pamět a vlastní identitu, která je dotvářena živelně ve velmi krátkém časovém úseku. Původ obyvatel z podstaty své různorodosti redukuje možnost vytvoření nové, společné kolektivní identity, osidlování připomíná pověstný tavicí kotel: „Když drmolili, jeden si připadal jako v Polsku, Mad’arech nebo na Ukrajině a někdy taky jako mezi cikánama. [...] Zkrátka byla to sebranka. Guláš hanáckých, podkrušnohorských, celkově moravských, podtatranských a jiných soudruhů s mírnou převahou umírněných Čechů a ošklivou menšinou cikánů“ (HŮLOVÁ 2010: 25). Patrná je funkční paralela mezi mládím Krakova a hlavní hrdinky, jejíž vzpomínky sahají do věku tří let, tedy do momentu, kdy se její rodina jako jedna z prvních přistěhovala. Uniformita města podtrhující rovnostářskou ideologii je vypravěčkou zřetelná a pocitována od samého počátku jeho existence; nabídka vybavení interiérů neobsahuje více než dvě možnosti. Charakter místa dokonce evokuje sídelní celky Uzbekistánu a vnímání unifikace tak získává mezinárodní rozměr, odkazující ke společné ideologii států východního bloku: „[...] a ty nepodařený města prej vypadaj podobně“ (HŮLOVÁ 2010: 20). Státní politika proniká do krakovského veřejného prostoru také ve verbalizované podobě - v projevech straníků při otevírání nových podniků, textech plakátů, nástěnek: „V Krakově to všechno stálo na slovech“ (HŮlOVÁ 2010: 26).

Vzhledem k této pozici Krakovu jakožto místu bez tradice chybí významný aspekt šíření ideologie - poukaz na její minulost, zásluhy a oběti z doby, kdy ještě nebyla oficiální a o své místo teprve bojovala. Dialektika minulosti a současnosti (vymezení přítomnosti oproti dřívějšku) je přitom součástí ideologického programu (LeGOFF 2007: 21). Prostor postrádá pamětní desky odkazují-

7) Konkrétně ještě Drážd’any, Minsk, Charkov a Debrecín. Více ke specifikům jmen zahraničních měst v literárním textu DAVID 2011: 212. 
cí na pobývání představitelů ideologie, památné lokality střetů s dřivější mocí či místa veřejných manifestací a proklamací a podobné stopy minulosti běžné $\mathrm{v}$ historických městech nesídlištního typu. Neuralgickým předělem je proto v knize odhalení hrobu neznámého vojáka. V novém urbánním prostoru je zmíněný monument jediným hmotným místem mocensky prosazované paměti. Ve svém konceptu označuje Pierre Nora jako místa paměti „vše, co se váže ke kultu mrtvých, vše, co je součástí dědictví, zajištuje přítomnost minulosti v přitomnosti“ (NORA 1996: 58), v tomto konkrétním případě hrob reprezentuje připomínku osvobození země Sovětským svazem. Charakter místa paměti akcentuje také heslo Nikdy nezapomeneme, vyryté v podstavci sochy partyzána.

Není přitom možné odhlédnout od typu paměti, který má monument vytvářet, a od způsobu, jakým tak činí. Využijeme-li v českém prostředí méně známý koncept paměti francouzského filosofa Paula Ricœura ${ }^{8}$, můžeme zařadit tuto pamět mezi tzv. zneužitou. Ricœur ji dále rozpracovává - jednotlivými typy jsou pamět potlačená, manipulovaná a povinná. Hrob neznámého vojína naplňuje především znaky manipulované paměti (osvobození Rudou armádou je využito k nesouvisejícím politickým a mocenským ambicím). Její vztah k ideologii připomíná i sám Ricœur: „To, co má ideologie za cíl legitimizovat, je autorita řádu a moci - řádu ve významu vztahu mezi celkem a částí, moci ve významu hierarchie mezi vládnoucími a ovládanými“ (RICCEUR 2000: 101). Záměrem je přitom identifikace obyvatel s vládnoucí ideologií a vytvoření pocitu jednoty: „[...] nucené vštěpování do paměti přidává výhodu opětovného připomínání peripetií společné minulosti, považovaných za základy společné identity“(RICCEUR 2000: 104). Cílená manipulace paměti je tak, jak dokládá výše uvedený př́iklad krakovského monumentu, podstatným ideologickým zásahem do prostoru socialistického města.

Oproti Strážcům občanského dobra můžeme vysledovat poněkud odlišnou genezi (a v některých rysech z něj plynoucí celkovou povahu) sídlišt v prózách Jana Balabána. Autorův prostor nových sídlištních čtvrtí obvykle nevyrůstá uprostřed „území nikoho“ jako v případě modelového prostoru Krakova; je výrazněji charakterizován v protikladu ke starším částem města; jedná se o území bývalých vesnic či okrajových částí původních měst. ${ }^{9}$ Balabán v tomto smyslu navazuje na linii „ekologických“ děl, v nichž je kriticky hodnocen dopad masivní výstavby na krajinu a př́rodu. Podobně nahlíží proces rapidního rozrůstání

8) Koncept je představen v přibližně šestisetstránkové práci La mémoire, l’histoire, l'oubli (Pamět, dějiny, zapomnění), která nebyla doposud do češtiny přeložena.

9) Podrobněji se proměnami městského prostoru v díle Jana Balabána zabývala Izabela Mroczek (MROCZEK 2011: 154-164). 
pražských sídlišt do extravilánu např. Pavel Verner ve svém debutu, společenském románu Dranciáš (k drancování odkazuje ostatně i titul knihy).

Topos sídliště má v prózách Jana Balabána bytostný předobraz v prostředí Ostravské aglomerace (STŘELEC 2016: 112). Samotné umístění sídlišt tak odráží jeden $\mathrm{z}$ vrcholů socialistické ideologie - práci a průmyslovou výrobu spojenou s potřebou ubytování zaměstnanců a jejich rodin. ${ }^{10}$ Sídlištní celky jsou situovány tak, aby to bylo výhodné s ohledem na přepravu občanů do gigantických průmyslových podniků, také infrastruktura podléhá tomuto požadavku: „Bylo to bydlení pro lepší lidi, než celou čtvrt’ sevřela z jedné strany fabrika, z druhé dálnice, $\mathrm{z}$ třetí trat'. Stala se $\mathrm{z}$ ní periferie $\mathrm{v}$ samém středu města" (BALABÁN 2010: 245). Výstavba zdůrazňuje socialistickou společnost s ideologickými atributy jako novost, mladost, pokrok - nekompromisní boj se vším starým, nepokrokovým a reakčním se v urbánním plánu manifestuje degradací citované „buržoazní“ městské čtvrti. Takto ztvárněný fikční prostor naplňuje funkčně podstatu ideologického státního aparátu, formujícího identitu subjektů společnosti (DROZDOWICZ - MLČOCH 2016: 11).

Jestliže jsme na fikční prostor Strážců občanského dobra aplikovali typologii zneužité paměti, v tomto a dalších případech lze topos sídliště paralelně nahlížet skrze Ricœurovu figuru potlačené paměti a zapomnění. Potlačování paměti se děje v duchu vymazávání stop (effacement des traces), ${ }^{11}$ tedy na materiální úrovni. Toto materiálno tvoři prvky prostoru pocházející z doby před nástupem zmiňované ideologie; jeho potlačování je srovnatelné s vymazáváním ideologicky nevhodných prvků minulosti ve všech doménách veřejného diskurzu (média, oficiální svátky, učebnice dějepisu apod.).

Ideologii v prostoru sídliště tak odráží i nepřítomné prvky, to, co do něj záměrně není zakomponováno. Sídliště z novely Kudy šel anděl má „[...] etapy a v etapách byty a obchodní střediska a kulturní střediska a kavárny pro pracující" (BALABÁN 2011: 250). Enumerací je rovněž prezentována vybavenost sídliště Severní Město v Rudišově Národní trídě: „A kino a kulturák a tuhle mysliveckou hospodu [...] a hřiště a parky a jesle, kde pak dělala moje máma, a mateřskou školku a základní školu a taky zvláštní školu a učňák a průmyslovku a gympl a nákupní centrum, co se mu říká Bajkonur, a polikliniku a porodnici a hřbitov a fízlárnu [...]" (RUDIŠ 2013: 22). Je evidentní, že oproti jádru tradičního města v těchto lokalitách

10) Srov. také MÁLKOVÁ 2012: 238-239.

11) Ricœur vychází u pojmu stopa z neurologického významu a rozšiřuje jej o další, stopy nikoliv biologického rázu. Srov. RICCEUR 543-553. 
absentují některé dominantní objekty - typicky duchovní. ${ }^{12}$ Státní a ideologická monopolizace tímto vstupuje i do tradičního životního cyklu člověka, v předcházejících generacích strukturovaného ve velké míře právě ve svatostáncích, kde se, jak připomíná Marie Kubínová, „odehrávají také obřady spjaté s nejdůležitějšími momenty individuální lidské existence: se zrozením (křest), se zaslíbením se životnímu partnerovi a potenciálním vznikem životů dalších (sňatek), a konečně se smrtí (v kostele probíhá první fáze pohřebního obřadu) “ (KUBÍNOVÁ 1997: 133). Nežádoucnost církve je formulována i v její nepotřebnosti, vyvážené dříve nesamozřejmým materiálním a konzumním pohodlím: „Ne jak někde na kotárech, sedm kilometrů pěšky do kostela. Všechno máš při ruce, všechno, co potřebuješ“ (BALABÁN 2007: 66). Toto směřování $\mathrm{k}$ diskontinuitě rodové paměti a rituálů či způsobu života je konstruováno v duchu ideologického požadavku na zřetelný předěl mezi „starým“ a „novým“, „pokrokovým“.

Přihlédneme-li k vizuálnímu charakteru sídlištních celků, nápadnou a opakovanou metaforou se pro ně stává předobraz hradu, hradeb či opevnění. Ten je často akcentován prudkým kontrastem mezi monolitickým, jednobarevným okrajem sídliště a okolní volnou krajinou, který vznikl živelně se rozšiřující zástavbou, jako v reprezentaci pražského sídliště v románu Stanislava Komárka Mandaríni: „Na rozrušené zemi nebylo na první pohled nic vidět, a když se za večerního šírání blížil ku Praze, zdála se mu hradba paneláků na jejím okraji jako jakési obludné opevnění, jako z nějakého dávného zfilmování verneovek. Proti barvami, reklamami a světly hýřícímu Mnichovu se mu hlavni město zdálo šedivé, zbědované, jako po těžké nemoci, bezbarvé obchody byly už vesměs zavřené, ulice skoro prázdné“ (KOMÁREK 2011: 52). Podobně vnímá své sídliště Jaromír v Balabánově povídce Triceratops: „Šikmé sluneční paprsky se opíraly do hradeb panelových domů. Některá okna byla zcela zalita měděným světlem. Leskla se jako bronzové štíty bojovníkü“ (BALABÁN 2007: 99). V případě Rudišovy Národní tř́dy je obraz hradu obohacen o vypravěčovo vědomí sounáležitosti a obrany: „Nasaju do sebe ten ledovej vzduch. Je mi dobře. Vidím ty vysoký paneláky. Tu vysokou vozovou hradbu. Tu naši betonovou pevnost. Hrad, kde sem doma a kterej hájím“ (RUDIŠ 2013: 46).

Připomeňme, že v literatuře se objevuje již od poloviny 18. století dvojí podoba hradu; jednak v podobě opuštěného hradu jako romantická připomínka minulosti, hmatatelného plynutí času a působení přírody, jednak jako tajemný, záhadný,

12) Ale také další, např. archivy či muzea, tedy takové objekty, které odkazují k minulosti a vedou ke (komunistickou ideologií nežádoucímu) vnímání kontinuity; v pojetí již zmíněného Pierra Nory jde o místa paměti (NORA 1996: 40-63). 
rozhlehlý prostor připomínající labyrint. Bloky panelových domů v citovaných dílech, ony mohutné „hradby“ do výše vzedmuté z krajiny, se sémanticky vztahují k tomuto druhému pojetí toposu hradu. Jde o místo, kterému dominuje „hrůzostrašná architektura, jejíž labyrintické, nekonečné útroby“ jsou „záměrně hypertrofované“ (HRBATA 1997: 29). Odosobněný svět neumožňující identifikaci člověka s prostředím se jeví jako výsledek ideologické snahy o rovnost a z ní plynoucí stejnost; přesto skrze podobu sídliště prosvítá i opačné vědomí: „Prase to muselo být! Ten architekt, který nakreslil a postavil dům s balkonem metr dvacet nad zemí jako s pozváním pro zloděje. Hovado, které ví, že v těch domech [...] nikdy nebude bydlet. At’ si to zamřížují, otroci, řekne si, když vykračuje přes trávníček ke své vile postavené z peněz, které tu všude chybějí. Nic si neřekne. Na otroky nemyslí ani vteřinu“ (BALABÁN 2007: 21). Zmíněné mříže jako atribut vězení, uzavření a nesvobody jsou gradací atmosféry pevnosti či opevnění. V reprezentaci prostoru sídliště nejde o novum - tato kritická asociace se v české literatuře objevuje již v 70. letech, v době vrcholu tuzemské panelové výstavby: „[...] sada betonových klecí v pátém patře paneláku s výhledem na protější stejně ohyzdný panelák. [...] Několika reprodukcemi francouzských impresionistů [...] jsem učinila toto cementové vězení téměř obyvatelným“ (PÁRAL 1978: 10).

Tuto (ne)obyvatelnost panelového domu přivádí do krajní podoby Miloš Urban - přestože dominantním prostorem románu Sedmikostelí je historické jádro Prahy, vykreslen je zde i osud inovativního sídlištního bloku na Jižním Městě. Technologický experiment s novými, nevyzkoušenými karcinogenními materiály se stává příčinou náhlých úmrtí obyvatel domů; hrůzný obraz paneláku „požírajícího“ obyvatele zevnitř tak převrací očekávaný motiv domova v místo zhouby, rakoviny. Normalizační atmosféra přirozeně neumožňuje o fatálním selhání národního podniku hovořit: „V osmdesátých letech na jejich experiment doplatilo devatenáct lidí, jedenáct $\mathrm{z}$ nich nezletilých. O aféře se v odborných kruzích vědělo, ale nesmělo se o ní mluvit. Mlčeli ti, kteří to spáchali, i ti, kteří to schválili“" (URBAN 2001: 268). Metafora hradu v Urbanově próze směřuje k jeho vnitřnostem, či přesněji, transponuje je do podoby smrtící kobky.

Interiér domů, zejména topos bytu a pokoje, přesto zůstává intimnější částí prostoru sídliště. Jak ve všeobecné platnosti upozorňuje Hodrová, „pokoj je jedním ze základních míst lidské existence“ (HODROVÁ 1997: 217). Současně komunikuje jak s vnějším prostorem, tak s jeho obyvateli, balancuje mezi uzavřeností a otevřeností (HODROVÁ 1997: 219). Tvoří tím mezistupeň spojující veřejný prostor a osobní sféru člověka; v námi pojednávaných dílech nabývá významu v napětí mezi „oficiálním“, ideologicky formovaným vnějškem 
a jeho popřením. ${ }^{13}$ Ostatně kontrast se objevuje i mezi samotným prostorem bytů a společných chodeb, jako např. na fikčním pražském sídlišti v románu Stanislava Komárka Mandaríni: „Cesta výtahem do desátého patra, stále ještě ne nejvyššího, na ni působila jako věčnost, komunistická manýra uprášených chodeb a poloprázdných nástěnek $\mathrm{v}$ domě na ni dýchla dříve nepoznanou měrou. Byt byl naopak zařízen zcela útulně, v křiklavém nepoměru k sociální polopoušti všude okolo. Její nový obdivovatel otevřel lahev a nalil dvě sklenice, ale sám jen zlehka ulizoval“" (KOMÁREK 2011: 115).

Komárek zde vytváří atmosféru pokoje také protikladem rozměrů - malá garsonka svou nepatrností evokuje zapomenutí na masivnost (a masovost) exteriéru, která přetrvává i v porevoluční době: „Ač si to úplně nepřipustila, přijala $\mathrm{s}$ radostí Jaroslavovo pozvání - má tu auto a mohli by si dále povídat v jeho garsonce na Jižním Městě. Zmiňovaný vůz, BMW, parkoval skutečně za rohem a za chvíli už ujížděli směrem $k$ panelové džungli. Jednu $z$ věží tohoto rejdiště nakonec Jarda vybral a zastavil poblíž, byt’ bylo nutno dojít ještě značný kus. Svět, na nějž nebyla zvyklá, pustý, neosobní a bez infrastruktury, na ni dýchl zvláštní cizotou a Zuzana cítila, že proti svému původnímu přesvědčení dostává strach“ (KOMÁREK 2011: 115).

Výrazným motivem reprezentace ideologie v prostoru sídliště je také toponymie, ${ }^{14}$ jak jsme již naznačili v případě pojmenování Krakova ve Strážcích občanského dobra. Pojmenovací akt lze chápat jako silný mechanismus, jímž tematizovaná státní moc proniká do každodenního života s cílem posílit a udržet svou legitimitu: „Pojmenovávání míst představuje v současných společnostech zásadní prvek ve vztahu mezi místem a politikou identity. V tomto smyslu je pojmenovávání prostředkem normování. Názvy míst jsou součástí symbolického i materiálního řádu, který vytváří legitimitu pro ty, kdo ovládají politiku reprezentace (místa)“ (BERG-KEARNS 2009: 19). Literární toponyma sídliště tak postavy znají, vnímají, nebot jsou součástí identity jejich životního prostoru; míra jejich dominance či přítomnosti jiných, neoficiálních či starších jmen se však liší.

13) Intimita a neoficiálnost bytu, symbolizující vnitřní svobodu člověka a jeho odstup od jinak všudypřítomné ideologie, však není samožrejmá. V normalizační literatuře (at̉již oficiální nebo samizdatové) je naopak mnohdy tematizováno vnikání „vnějšího světa“ i do niterného prostoru pokojů: „V tomto panelovém velkodomě je však soukromí nutno úporně hájit, je zde považováno za cosi až neslušného - zato neohlášené vpády platí za samozřejmost" (PÁRAL 1978: 10); „U nich v domě např́klad byli samí fízlové. Černou ovcí byla rodina důstojníka armády. Nad nimi bydlel fízl-čaroděj. Viděl neviděné, slyšel neslyšené. Věděl, kdy jde na záchod, kolika papíry si utřel prdel a jestli měl tvrdou stolici. Skrytá kamera fotografuje zespoda jeho řit a tím snímkem ho budou strašit ve dne v noci“ (PLACÁK 1990: 89). V citovaném Placákově Medorkovi tak ani byt neumožňuje prožívat pocity bez dohledu, jediných východiskem jsou jeho chaotické fantaskní sny.

14) Více o ideologii a moci ve vztahu k pojmenovávání míst srov. např. DAVID-MÁCHA 2014: 38-39. 
Tyto typy pojmenování přecházejí v Rudišově Národní tř́idě do dlouhodobého pojmenování a překonávají epochu ideologie svého vzniku jako nákupní centrum Bajkonur a hotel Sputnik (RUDIŠ 2013: 22), jindy odrážejí změnu politické orientace: „Ten kickboxovej střelec z doby, kdy sem na něj chodil do kina, který se jmenovalo Kosmos, ale už se tak nejmenuje, protože ted’ z něj je kasíno, který se jmenuje Las Vegas“ (RUDIŠ 2013: 22). V námi analyzovaných Balabánových prózách je sledována původní vrstva jazykové krajiny, mizející společně se zánikem venkovského rázu prostoru, jako např. urbanonyma Na návsi či Pod hrází v reflexivní povídce Most ze souboru Jsme tady (BALABÁN 2010: 334). Povinná pamět vládní ideologie naopak v nových sídlištích integruje a prosazuje honorifikační toponyma, jejichž nadužívání je nahlíženo parodicky: „Bylo to v restauraci Stalingrad, které sídlištní chuligáni neřekli jinak než U Hitlera, a to přesto, že se tehdy učitelé dějepisu snažili zatajit svým svěřencům paralely obou velikánů, seč mohli. [...] Zkrátka Martin Vrána a Tonda Gona si dali pivo U Hitlera a nikde jinde“ (BALABÁN 2011: 242). V Komárkově románu je v jednom případě lidová toponymie inspirována také děním na druhé straně železné opony: „Když Jindřich dojel do bytu svých rodičů na sídlišti lidově zvaném Texas - stavělo se v době atentátu na Kennedyho -, byla už černočerná tma“" (KOMÁREK 2011: 53).

Samostatnou pozornost věnujme jiným případům názvi̊ míst - takovým, kdy jsou naopak sídlištní pojmenování nepřítomna. Zatímco Krakov Petry Hůlové je postrádá prozatímně, Balabánův román Kudy šel anděl představuje sídlištní město, v němž je počítáno s trvalým pojmenováním čtvrtí pouze číslicí - jednotlive části tedy nesou název Etapa, následovaný číslovkou dle postupující výstavby sídliště. Příznačný termín etapa rovněž obsahuje ideologickou konotaci; zatímco tradiční pojmy čtvrt či obvod odkazují k prostorovému vymezení, etapa se svým významem úseku či období daleko spíše vztahuje k časové hierarchii a zdůrazňuje samotný akt budování nového urbánního prostoru.

\section{Závěr}

Jak ukazují prezentované dílčí sondy do vybraných současných českých próz, literární obraz socialistického sídliště se úzce spájí s reprezentací politické ideologie doby. Konstrukce fikčního prostoru přejímá rysy politické doktríny, které jsou nedělitelnou součástí jeho paměti; sídlištní celky tak v literatuře představují výrazné místo paměti komunistické epochy. Signifikantní je v tomto ohledu 
ustálení literárních principů a motivů, jimiž se státní ideologie v prostoru sídliště stává přítomnou, byť ne v každém $\mathrm{z}$ analyzovaných děl ve stejné míře. Jedná se zejména o princip unifikace (jednotný vzhled budov, unitární vybavení interiéru, číslování části sídliště namísto slovního pojmenování), princip vnucování a potlačování paměti (zánik paměti původní lokality, hyperbolizované připomínání politické paměti, honorofikační toponyma, ruptura ve způsobu života) a princip hradu, pevnosti a labyrintu (motiv nesvobody, vnitřního uzavření, ale i rozkladu). Tyto aspekty se výrazným způsobem podílejí na kolektivní paměti a identitě fikčního toposu sídliště - prostoru ideologie sui generis.

Tato studie je výstupem z projektu SGS01/FF/2018 Vybrané žánrové a subžánrové proměny $v$ současné české literatuře II.

\author{
PRAMENY \\ BALABÁN, Jan \\ 2007 Možná že odcházíme (Brno: Host) \\ 2010 „Jsme tady“, in Povídky (Brno: Host), s. 307-472 \\ 2011 „Kudy šel anděl“, in Romány a novely (Brno: Host), s. 223-402 \\ HŮLOVÁ, Petra \\ 2010 Strážci občanského dobra (Praha: Torst)
}

KOMÁREK, Stanislav

2011 Mandaríni (nepravidelný román) (Brno: Host)

PÁRAL, Vladimír

1978 Radost až do rána: o kréčcich a lidech (Praha: Melantrich)

PLACÁK, Petr

1990 Medorek (Praha: Lidové noviny)

RUDIŠ, Jaroslav

2013 Národní tř́da (Praha: Labyrint)

URBAN, Miloš

2004 Sedmikostelí: gotický román z Prahy (Praha: Argo)

VERNER, Pavel

1989 Dranciáš: Prováděcí projekt pádu (Praha: Mladá fronta) 
Karel Střelec

Prostor ideologie. Varianty motivu sídliště v současné české próze

\section{LITERATURA}

ANDRUSZ, Gregory D.

1987 „The built environment in Soviet theory and practice“, International Journal of Urban and Regional Research. 11(4), s. 478-499

DAVID, Jaroslav

2011 Smrdov, Brežněves a Rychlonožkova ulice: kapitoly z moderní české toponymie: místní jména, uliční názvy, literární toponyma (Praha: Academia)

DAVID, Jaroslav - MÁCHA, Přemysl

2014 Názvy míst: pamět, identita, kulturní dědictví (Brno: Host)

DEMKO, George - REGULSKA, Joanna

1987 „Socialism and its impact on urban processes and the city“, in Urban geography. 8(4), s. 289-292

DROZDOWICZ, Maksymilian - MLČOCH, Jan

2016 „Introducción“, in J. Mlčoch a M. Drozdowicz: Ideando: búsquedas ideológico-literarias en Hispanoamérica (Ostrava: Ostravská univerzita), s. 9-17

BERG, Lawrence D. - KEARNS, Robin A.

2016 „Naming as Norming: Race', Gender and the Identity Politics od Naming Places in Aotearoa / New Zealand“, in L. D. Berg a J. Vuolteenaho (eds.): Critical Toponymies. The contested Politics od Place Making (Abingdon - New York: Routledge) s. 19-52

GRUMBERG, Karen

2011 Place and Ideology in Contemporary Hebrew Literature (Syracuse - New York: Syracuse University Press)

HODROVÁ, Daniela

1997 „Smysl pokoje“, in D. Hodrová et al.: Poetika míst: kapitoly z literární tematologie (Jinočany: H\&H), s. 217-238

HRBATA, Zdeněk

1997 „Hrady a jejich zř́ceniny“, in D. Hodrová et al.: Poetika míst: kapitoly z literární tematologie (Jinočany: H\&H), s. 25-42

KUBÍNOVÁ, Marie 1997 „Prostory víry a transcendence“, in D. Hodrová et al.: Poetika míst: kapitoly z literární tematologie (Jinočany: H\&H), s. 125-176

Le GOFF, Jacques

2007 Pamět' a dějiny (Praha: Argo)

LUKAVEC, Jan

2008 „Sídliště (a Jižní Město) v literatuře“, iLiteratura.cz; dostupné z: <http://www.iliteratura.cz/ Clanek/29433/sidliste-a-jizni-mesto-vliterature >, př́stup 13.1. 2018 
MÁLKOVÁ, Iva

2012 „Industriální Ostravsko jako literární krajina“, in J. Malura a M. Tomášek (eds.): Krajina: vytváření prostoru v literatuře a výtvarném umění. Ostrava: Filozofická fakulta Ostravské univerzity v Ostravě, s. 229-243

MROCZEK, Izabela

2011 „Proměny městského prostoru v díle Jana Balabána“, in J. Malura a M. Tomášek (eds.): Město:vytváření prostoru v literatuře a výtvarném umění (Ostrava: Filozofická fakulta Ostravské univerzity v Ostravě), s. 154164

NORA, Pierre

1996 „Mezi pamětí a historií: problematika míst“, in Antologie francouzských společenských věd: Město, Alban Bensa - Václav Hubinger (eds.) (Praha: Francouzský ústav pro výzkum ve společenských vědách)

NOVOTNÁ, Barbora

2010 „Panelák jako symbol a místo paměti“, Sociální studia 7(3), s. 127-131

RICCEUR, Paul

2000 La mémoire, l'histoire, l'oubli (Paris: Seuil)

STRAKOŠ, Martin

2011 Nová Ostrava a její satelity: kapitoly z dějin architektury 30.-50. let 20. století (Ostrava: Národní památkový ústav, územní odborné pracoviště v Ostravě)

STŘELEC, Karel

2016 „Ostrava v publicistice Jana Balabána“, Protimluv, 15(3-4), s. 112-116

ZMĚLíK, Richard

2011 „Ke třem konceptům městského prostoru: město jako sít v pojetí D. Hodrové, hledání ur-kódu města u V. N. Toporova a antropologie města J. Derdowské“, in J. Malura a M. Tomášek (eds.): Město: vytváření prostoru v literatuře a výtvarném umění (Ostrava: Filozofická fakulta Ostravské univerzity v Ostravě), s. 25-34

Mgr. Karel Střelec, karel.strelec@osu.cz, Katedra české literatury a literární vědy, Filozofická fakulta Ostravské univerzity, Ostrava, Česká republika / Department of Czech Literature and Literary Criticism, Faculty of Arts, University of Ostrava, Ostrava, Czech Republic 